\title{
Effect of 10\% Carbamide Peroxide Bleaching on Sound and Artificial Enamel Carious Lesions
}

\author{
Cristiane Franco PINTO ${ }^{1}$ \\ Adriana Franco PAES LEME \\ Vanessa CAVALLI ${ }^{3}$ \\ Marcelo GIANNINI ${ }^{1}$ \\ ${ }^{1}$ Departament of Restorative Dentistry, Dental School of Piracicaba, State University of Campinas, SP, Brazil \\ ${ }^{2}$ Center for Applied Toxinology, CAT/CEPID, Butantan Institute, São Paulo, SP, Brazil \\ ${ }^{3}$ Departament of Dentistry, University of Taubaté, SP, Brazil
}

\begin{abstract}
This study evaluated the effect of $10 \%$ carbamide peroxide (CP) bleaching on Knoop surface microhardness (KHN) and morphology of sound enamel and enamel with early artificial caries lesions (CL) after pH-cycling model (pHcm). Human dental enamel blocks were randomly divided into 6 groups $(\mathrm{n}=10)$ : 1 - sound enamel bleached $(\mathrm{S})$ with CP (Rembrandt/Den-Mat); 2 - S and submitted to pHcm; 3 - CL bleached with CP; 4 - CL stored in artificial saliva and submitted to pHcm; 5 - CL treated with placebo gel and submitted to pHcm; 6 - CL bleached with $\mathrm{CP}$ and submitted to pHcm. Enamel blocks with known initial KHN values were demineralized (groups 3 to 6) and submitted to 12 day pHcm (groups 2, 4, 5 and 6). After demineralization and treatments, KHN was determined and the specimens were examined using scanning electron microscopy (SEM). Data were analyzed statistically by ANOVA and Tukey's test at 5\% significance level. The results showed that among CL groups (3 to 6) only the group 3 presented remineralization after treatments. S groups (1 and 2) showed higher KHN and presented less formation of porosities on enamel surface than CL groups after treatments. In conclusion, bleaching procedures on enamel with CL did not exacerbate the demineralization, but should be indicated with caution.
\end{abstract}

Key Words: carbamide peroxide, caries lesions, dental enamel, microhardness, scanning electron microscopy.

\section{INTRODUCTION}

Carbamide peroxide is the active ingredient in most home-bleaching agents. Since the introduction of nightguard vital whitening, concern has been expressed regarding the potential effects of carbamide peroxide solution on dental hard tissues (1). As the bleaching technique of vital teeth comprises the direct contact of the whitening gel on the outer enamel surface, the oxidation reaction for an extended period of time can be related to demineralization effects $(2,3)$.

Various effects of carbamide peroxide bleaching on teeth have been studied. Scanning electron microscopy (SEM) investigations have shown that $10 \%$ carbamide peroxide changes enamel, such as surface dissolution and topographical alterations, exposing a porous surface (4-6). The morphological changes and reduction of enamel microhardness are not limited to the enamel surface. Alterations have also been detected in the subsurface enamel layer (7-9).

Moreover, some studies have shown alterations of the histological aspects and composition of sound dental enamel after carbamide peroxide gel application $(9,10)$. The bleaching treatment with $10 \%$ carbamide peroxide slightly increased caries susceptibility of enamel $(11,12)$. However, it is not known the effect of carbamide peroxide gels on enamel with early caries lesions. The objective of this study was to evaluate the effect of $10 \%$ carbamide peroxide bleaching on surface microhardness and morphology of sound enamel or

Correspondence: Prof. Dr. Marcelo Giannini, Departamento de Odontologia Restauradora, Área de Dentística, Faculdade de Odontologia de Piracicaba, Universidade Estadual de Campinas, Av. Limeira, 901, 13414-903 Piracicaba, SP, Brasil. Tel: +55-19-2106-5338. Fax: +5519-2106-5218. e-mail: giannini@fop.unicamp.br 
enamel with early artificial caries lesions during $\mathrm{pH}-$ cycling model. The hypothesis tested was that the bleaching treatment can alter enamel microhardness and morphology, increasing the mineral loss of enamel with early artificial caries lesions.

\section{MATERIAL AND METHODS}

\section{Experimental Design}

Erupted human third molars, stored in saturated thymol solution at $5^{\circ} \mathrm{C}$ for at least one month were used in this study. The teeth were obtained after informed consent by the patients and under protocol (\#141/2002) approved by the local Research Ethics Committee of Piracicaba Dental School, State University of Campinas, Brazil.

Dental enamel blocks $(4 \times 4 \times 3 \mathrm{~mm})$ were obtained from teeth and enamel surfaces were wet-polished with 600- and 1200-grit aluminum oxide abrasive papers and diamond paste $(1 \mu \mathrm{m})$. Sixty enamel blocks with known mean microhardness $(404.6 \pm 4.5$ Knoop Hardness Number - KHN) were randomly divided into two groups: sound group and group that was exposed to a demineralization solution. After induction of artificial early carious lesions, 40 blocks with known surface microhardness were selected for the study and divided into 4 treatments. The experimental groups $(\mathrm{n}=10)$ are described bellow and summarized in Table 1: 1) $\mathrm{S}+10 \% \mathrm{CP}+\mathrm{AS}$ - sound enamel bleached with $10 \%$ carbamide peroxide gel (Rembrandt, Den-Mat Corp., Santa Maria, CA, USA) $(\mathrm{pH}=6.23)$ and stored in

Table 1. Experimental groups evaluated in this study.

\begin{tabular}{cccccc}
\hline Groups & S & CL & AS & $10 \%$ CP & pH-cycling \\
\hline 1 & Yes & No & Yes & Yes & No \\
2 & Yes & No & No & Yes & Yes \\
3 & No & Yes & Yes & Yes & No \\
4 & No & Yes & Yes & No & Yes \\
5 & No & Yes & No & No (PL) & Yes \\
6 & No & Yes & No & Yes & Yes \\
\hline
\end{tabular}

$\mathrm{S}=$ sound enamel; $\mathrm{CL}=$ Enamel with early artificial caries lesions; $\mathrm{AS}=$ immersion in artificial saliva; $10 \% \mathrm{CP}=$ treatment with $10 \%$ carbamide peroxide; $\mathrm{PL}=$ treatment with placebo. artificial saliva at $37^{\circ} \mathrm{C}$ after each daily bleaching treatment; 2) $\mathrm{S}+10 \% \mathrm{CP}+\mathrm{pHcm}$ - sound enamel bleached with $10 \%$ carbamide peroxide gel and subjected to $\mathrm{pH}-$ cycling model; 3) $\mathrm{CL}+10 \% \mathrm{CP}+\mathrm{AS}$ - enamel with early artificial caries lesions bleached with $10 \%$ carbamide peroxide gel and stored in artificial saliva at $37^{\circ} \mathrm{C}$ after each daily bleaching treatment; 4) $\mathrm{CL}+\mathrm{AS}+\mathrm{pHcm}$ enamel with early artificial caries lesions stored in artificial saliva at $37^{\circ} \mathrm{C}$ and subjected to $\mathrm{pH}$-cycling model; 5) $\mathrm{CL}+\mathrm{pl}+\mathrm{pHcm}$ - enamel with early artificial caries lesions treated with placebo gel (5\% glycerin, 1.2\% carbopol 940, pH 7.0 /Proderma Pharmacy, Piracicaba, SP, Brazil) and submitted to $\mathrm{pH}$-cycling model; 6) $\mathrm{CL}+10 \% \mathrm{CP}+\mathrm{pHcm}$ - enamel with early artificial caries lesions bleached with $10 \%$ carbamide peroxide gel and subjected to $\mathrm{pH}$-cycling model.

After these treatments, Knoop surface microhardness was determined for each group.

\section{Induction of Artificial Caries Lesions}

Forty surface enamel blocks with known surface microhardness were coated with acid-resistance varnish, excepted for an area of $8 \mathrm{~mm}^{2}$. The blocks (groups 3 to 6) were submitted to demineralized solution containing $50 \mathrm{mM}$ acetate buffer; $1.23 \mathrm{mM} \mathrm{Ca} ; 0.73$ $\mathrm{mM} \mathrm{P}, 0.1 \mathrm{ppm} \mathrm{F}$, pH 5.0 for $32 \mathrm{~h}$ at $37^{\circ} \mathrm{C}$ using $2 \mathrm{~mL}$ of solution to each $1 \mathrm{~mm}^{2}$ of exposed area $(13,14)$. Enamel blocks with surface microhardness mean of $28.9 \pm 0.4 \mathrm{KHN}$ units were selected.

\section{Treatments and $\mathrm{pH}$-Cycling Regimen}

The blocks (groups 2,4,5,6) were subjected to a 12-day $\mathrm{pH}$-cycling $(13,14)$ consisted of five phases: 1$)$ 1 -min soak in fluoridated dentifrice $(1100 \mathrm{ppm} \mathrm{F}$ as $\mathrm{NaF}$ )/water slurries twice a day to simulate daily toothbrushing; 2) between the treatments with dentifrice, samples were individually immersed in artificial saliva at $\left.37^{\circ} \mathrm{C} ; 3\right)$ to simulate the daily acid challenge, enamel blocks were individually immersed in demineralized solution for $2 \mathrm{~h}$ at $37^{\circ} \mathrm{C}$, with the same composition of the solution used in the initial carious lesion procedure; 4) the samples were immersed in human saliva during $2 \mathrm{~h}$ at $37^{\circ} \mathrm{C}$ before the bleaching treatment to promote acquired pellicle formation; 5) to simulate daily treatment, the samples were exposed to artificial saliva (group 4), placebo gel (group 5), whitening gel 
(groups 2 and 6) for $8 \mathrm{~h}$ (nocturnal period) at $37^{\circ} \mathrm{C}$. In each specimen, $0.1 \mathrm{~mL}$ of the artificial saliva, placebo gel or whitening gel and $0.05 \mathrm{~mL}$ of artificial saliva, placebo gel or whitening gel) and $0.05 \mathrm{~mL}$ of artificial saliva were applied on enamel surface and covered with an individual tray. During bleaching, the specimens were placed in $100 \%$ relative humidity at $37^{\circ} \mathrm{C}$. After bleaching, the specimens were rinsed with an air/water spray for 10 $\mathrm{s}$ and stored in humidity environmental until analysis.

\section{Microhardness Analysis}

Surface microhardness was determined in the enamel blocks before (baseline), after demineralization and after experimental treatments. A microhardness tester (FM-1e; Future Tech, Tokyo, Japan) with a Knoop indentor was used under a 50 -g load for $5 \mathrm{~s}$. Five indentations spaced $100 \mu \mathrm{m}$ from each other, from the baseline and from those made after demineralization were performed. Data were analyzed statistically by two-way ANOVA and Tukey's test at a 5\% level of significance.

\section{Scanning Electron Microscopy}

Two specimens of each group were prepared for analysis with a scanning electron microscope (JSM 5600; JEOL USA, Inc., Peabody, MA, USA). Specimens were sputter coated with gold in a vacuum evaporator (Desk II; Denton Vacuum Inc., NJ, USA, USA) and SEM micrographs of representative areas of the surfaces were taken at $\times 5,000$ magnification.

\section{RESULTS}

Table 1 presents the mean KHN values and standard deviations for experimental groups. Two-way ANOVA revealed statistically significant difference for both factors (treatments and interval measurements) $(p<0.01)$, and significant interaction between them $(p<0.01)$. The groups presented similar baseline mean $\mathrm{KHN}$ values ( $\mathrm{p}>0.05$ ). The enamel blocks (groups 3 to 6) that were exposed to the demineralizing solution did not differ statistically among each other $(\mathrm{p}>0.05)$. Also, these groups did not show statistically difference after treatments $(p>0.05)$. However, group 3 showed mineral gain after treatments $(p<0.05)$. Sound enamel surfaces submitted to bleaching procedures and not submitted to $\mathrm{pH}$-cycling model (group 1) showed the highest KHN values post-treatment, although, the bleaching treatment reduced the mean KHN value of sound enamel when compared to the baseline value $(\mathrm{p}<0.05)$.

Changes in enamel morphology after treatments were observed for all groups, with different levels of surface changes (Figs. 1 and 2). When the enamel was sound, minor alterations was induced by treatments (Figs. 1a and 1b). The carious enamel submitted to bleaching treatment and $\mathrm{pH}$-cycling model presented dissolution of some enamel superficial areas (Fig. 2d).

\section{DISCUSSION}

Recent studies have shown that treatment of enamel with either fluoridated dentifrice or acidic carbamide peroxide bleaching gels result in increased susceptibility to subsequent acid erosion and demineralization (15-17). However, it is not known if the $10 \%$ carbamide peroxide can promote similar effects on enamel with early caries lesion. The present study evaluated the effect of carbamide peroxide on artificial caries lesion during a pH-cycling model.

According to surface microhardness analysis (Table 2), the groups did not differ significantly in the baseline KHN values. Also, the groups that 

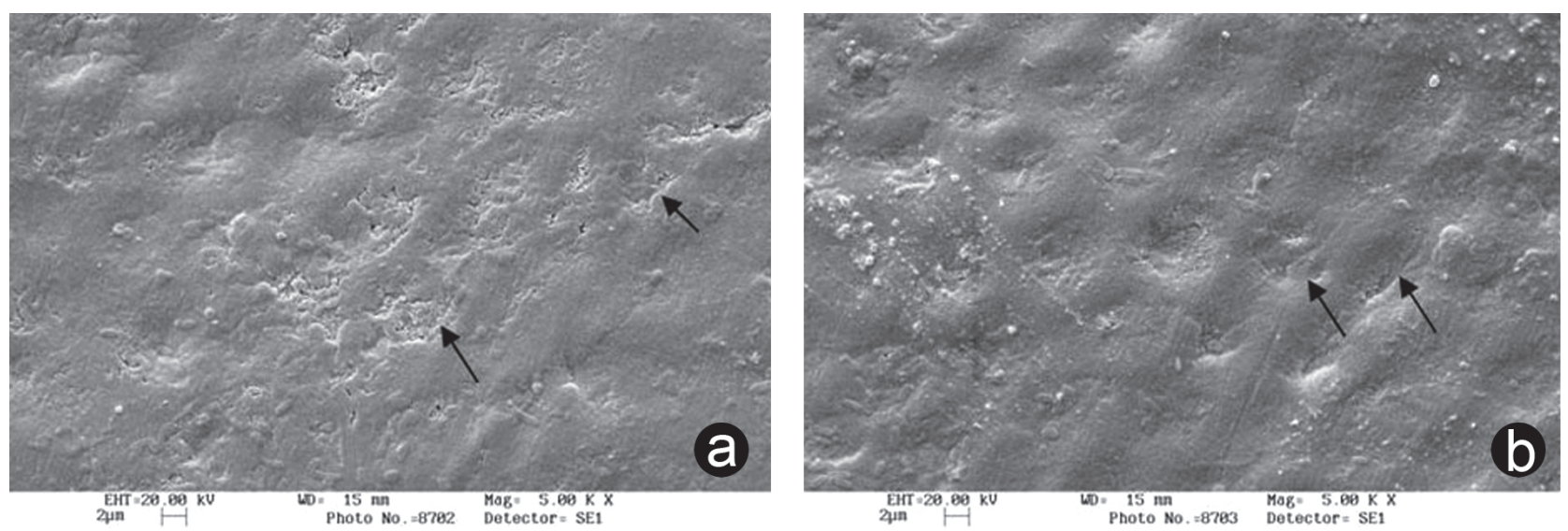

Figure 1. SEM micrographs illustrating the changes in enamel morphology after treatments. $\mathrm{A}=$ Sound enamel exposed to $10 \%$ carbamide peroxide; $\mathrm{B}=$ Sound enamel exposed to $10 \%$ carbamide peroxide and subjected to a pH-cycling model. Affected interprismatic structures (arrows) and porosities created by treatments can be noted on enamel surface.
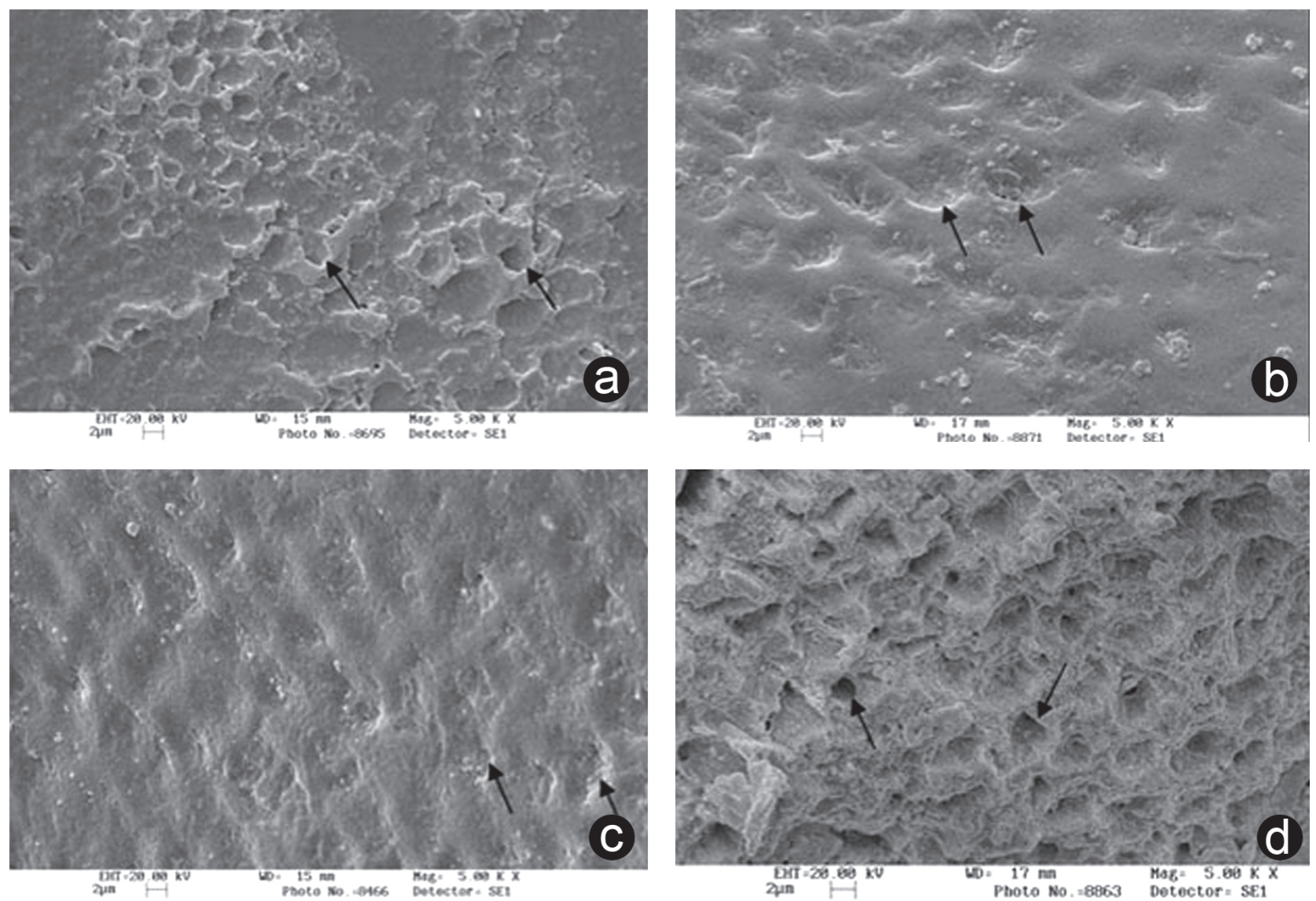

Figure 2. SEM micrographs of carious enamel submitted to bleaching treatment and $\mathrm{pH}$-cycling. $\mathrm{A}=$ Enamel with caries lesions exposed to $10 \%$ carbamide peroxide; $\mathrm{B}=$ Enamel with artificial caries lesions immersed in saliva and subjected to a $\mathrm{pH}$-cycling model; $\mathrm{C}=$ Enamel with artificial caries lesions exposed to placebo gel and subjected to $\mathrm{pH}$-cycling; $\mathrm{D}=$ Enamel with caries lesions exposed to $10 \%$ carbamide peroxide and submitted $\mathrm{pH}$-cycling. Affected interprismatic structures (arrows) can be noted. Erosion and total intraprismatic structure dissolution were observed only in group 6 (Fig. d). 
were exposed to a demineralization solution presented similar KNH values. The study showed homogeneity among the treatments before and after demineralization challenge and so the effect of the treatments could be tested in these groups. After treatments, the results showed that the sound groups ( 1 and 2) differed from each other and from the caries lesion groups $(3,4,5$ and 6). Groups 3, 4, 5 and 6 did not differ among each other.

Regarding the posttreatment analysis, group 1 $(\mathrm{S}+10 \% \mathrm{CP}+\mathrm{AS})$ showed mineral loss when compared to the baseline KHN values. These data confirmed the effect of carbamide peroxide in promoting enamel mineral loss $(1-4,16,18)$ and surface morphological changes $(4-9,16)$ (Fig. 1a). Group $2(\mathrm{~S}+10 \% \mathrm{CP}+\mathrm{pHcm})$ showed higher mineral loss than group 1most likely because it also underwent a 12-day $\mathrm{pH}$-cycling model simulating daily cariogenic challenge. Although, the enamel was treated twice with fluoridated dentifrice, it was not able to inhibit the demineralization because it was exposed to a combination of effects, such as $10 \%$ carbamide peroxide, which already increased the mineral loss (group 1), and pH-cycling. This non-effect of fluoride in inhibiting mineral loss can be attributed to the fact that carbamide peroxide could promote enamel dissolution or erosion (e.g.: intraprismatic structure removal) $(4,9,16)$, impairing accurate surface microhardness measurement; or perhaps the fluoridated dentifrice actually inhibited higher mineral loss, since it is established the effect of fluoride dentifrice on remineralizing artificial caries lesions $(13,14,19)$.

With respect to the groups with artificial caries lesion, only group $3(\mathrm{CL}+10 \% \mathrm{CP}+\mathrm{AS})$ showed statistically significant remineralization when compared to the post-demineralization $\mathrm{KHN}$ values. This group also showed the formation of porosities (Fig. 2a) due to exposure to carbamide peroxide and artificial saliva, while the other groups were subjected to $\mathrm{pH}$-cycling. Although the enamel blocks received daily treatment of $10 \%$ carbamide peroxide, these data suggested that artificial saliva was able to enhance surface microhardness, confirming the role of saliva in remineralizing caries lesion $(13,19,20)$.

Groups $4(\mathrm{CL}+\mathrm{AS}+\mathrm{pHcm}), 5(\mathrm{CL}+\mathrm{pl}+\mathrm{pHcm})$ and $6(\mathrm{CL}+10 \% \mathrm{CP}+\mathrm{pHcm})$ did not show statistically significant remineralization after $\mathrm{pH}$-cycling (Table 1). According to these results it can be suggested that the $10 \%$ carbamide peroxide can be indicated in situations of caries activity, since saliva and fluoridated dentifrice seems to inhibit higher mineral loss. Although 10\% carbamide peroxide bleaching (group 6) did not show statistically higher mineral loss when compared to the other groups (group 4-treated with artificial saliva and group 5- treated with placebo gel), the SEM micrographs revealed intraprismatic dissolution and lack of smoothness in some areas of enamel surface (Fig. 2d).

Some hypotheses could explain the non-statistically significant results among groups 4,5 and 6 . the small number of samples $(n=10)$ and the variability of samples, leading to high standard deviations; 2 . The demineralizing solution used in this study promotes high mineral loss without erosion and, perhaps, it was too aggressive showing $28.9 \pm 0.4 \mathrm{KHN}$ values. This high mineral loss could impair surface mineral recovery because the prisms could be totally disorganized, as reported by several authors (4-6) and observed in Figure $2 \mathrm{~d} ; 3$. The method used to evaluate mineral changes, Knoop microhardness test is an excellent method to determine the remineralization of caries lesions with fluoridated dentifrice, and maybe, the treatment with bleaching gel could alter the surface structure, masking the remineralization effect of saliva and fluoridated dentifrice; 4 . The results of this study do not agree with those of Costa and Mazur (18), who observed that remineralization of bleached enamel is improved by application of fluoride. However, those authors used high fluoride concentration while the present study used fluoride solution with the same dilution that occurs in mouth during toothbrushing.

In conclusion, the findings of the present study showed that carbamide peroxide bleaching promoted mineral loss of sound enamel. Although, the bleaching procedure did not exacerbate mineral loss of the carious enamel, it should be indicated with caution on enamel with caries activity.

\section{RESUMO}

Este estudo analisou o efeito do peróxido de carbamida a 10\% (PC) na microdureza Knoop de superfície (KHN) e morfologia do esmalte hígido e com lesões iniciais de cárie artificial (EC), após modelo de ciclagem de $\mathrm{pH}(\mathrm{cpH})$. Blocos de esmalte dental humano foram divididos aleatoriamente em 6 grupos $(n=10)$ : 1 esmalte hígido clareado (EHC) com PC (Rembrandt/Den-Mat); 2- EHC e submetido a $\mathrm{cpH}$; 3- EC clareado com PC; 4- EC armazenado em saliva artificial e submetido a cpH; 5- EC tratado com gel placebo e submetido a $\mathrm{cpH}$; 6- EC clareado com PC e submetido a cpH. Blocos de esmalte com a KHN conhecida eram desmineralizados (grupos 3 a 6) e submetidos a cpH (grupos 2, 4, 
5 e 6). KHN foi determinada após a desmineralização e os tratamentos. Os espécimes foram examinados através de Microscopia Eletrônica de Varredura (MEV). Os dados foram analisados através de ANOVA e teste de Tukey $(\mathrm{p}<0,05)$. Os resultados indicaram que entre os grupos com EC ( 3 a 6 ) somente o grupo 3 apresentou remineralização após os tratamentos. Os grupos EHC (1 e 2) mostraram maior KHN e menor formação porosidades quando comparados aos grupos EC após os tratamentos. Os procedimentos clareadores no esmalte com lesão de cárie não exacerbaram a desmineralização, entretanto precisam ser indicados com cautela.

\section{ACKNOWLEDGEMENTS}

This study was supported by grants $02 / 04135-3$ from FAPESP, Brazil. The authors are indebted to Dr. E. W. Kitajima (NAPMEPA/ESALQ-USP) for technical scanning electron microscopy support.

\section{REFERENCES}

1. Basting RT, Rodrigues AL Jr, Serra MC. The effect of $10 \%$ carbamide peroxide, carbopol, and/or glycerin on enamel and dentin microhardness. Oper Dent 2005;66:786-796.

2. Oliveira R, Paes Leme AF, Giannini M. Effect of a carbamide peroxide bleaching gel containing calcium or fluoride on human enamel surface microhardness. Braz Dent J 2005;16:103-106.

3. Faraoni-Romano JJ, Turssi CP, Serra MC. Concentrationdependent effect of bleaching agents on microhardness and roughness of enamel and dentin. Am J Dent 2007;20:31-34.

4. Pinto CF, Oliveira R, Cavalli V, Giannini M. Peroxide bleaching agent effects on enamel surface microhardness, roughness and morphology. Braz Oral Res 2004;18:306-311.

5. Perdigão J, Francci C, Swift EJ Jr, Ambrose WW, Lopes M. Ultra-morphological study of the interaction of dental adhesives with carbamide peroxide-bleached enamel. Am J Dent 1998;11:291-301.

6. Turkun M, Sevgican F, Pehlivan Y, Aktener BO. Effects of $10 \%$ carbamide peroxide on the enamel surface morphology: a scanning electron microscopy study. J Esthet Restor Dent 2002;14:238-244.

7. Basting RT, Rodrigues AL, Serra MC. Micromorphology and surface roughness of sound and demineralized enamel and dentin bleached with a $10 \%$ carbamide peroxide bleaching agent. Am J Dent 2007;20:97-102.
8. Akal N, Over H, Olmez A, Bodur H. Effects of carbamide peroxide containing bleaching agents on the morphology and subsurface hardness of enamel. J Clin Pediatric Dent 2001;25:293-296.

9. Cimilli H, Pameijer CH. Effect of carbamide peroxide bleaching agents on the physical properties and chemical composition of enamel. Am J Dent 2001;14:63-66.

10. Rotstein I, Danker E, Goldman A, Heling I, Stabholz A, Zalkind M. Histochemical analysis of dental hard tissues following bleaching. J Endod 1996;22:23-26.

11. Flaitz CM, Hicks MJ. Effects of carbamide peroxide whitening agents on enamel surfaces and caries-like lesion formation: an SEM and polarized light microscopic in vitro study. ASDC J Dent Child 1996;63:249-256.

12. Ganss C, Klimek J, Schaffer U, Spall T. Effectiveness of two fluoridation measures on erosion progression in human enamel and dentine in vitro. Caries Res 2001;35:325-330.

13. Paes Leme AF, Tabchoury CMP, Zero DT, Cury, JA. Effect of fluoridated dentifrice and acidulated phosphate fluoride application on early artificial carious lesion. Am J Dent 2003; 16:91-95.

14. Queiroz CS, Hara AT, Reis AF, Paes Leme AF, Cury JA. pHcycling models to evaluate the effect of low fluoride dentifrice on enamel de- and remineralization. Braz Dent J 2008;19:21-27.

15. Attin T, Kocabiyik M, Buchalla W, Hannig C, Becker K. Susceptibility of enamel surfaces to demineralization after application of fluoridated carbamide peroxide gels. Caries Res 2003;37:93-99.

16. Yeh ST, Su Y, Lu YC, Lee SY. Surface changes and acid dissolution of enamel after carbamide peroxide bleach treatment. Oper Dent 2005;30:507-515.

17. Menezes M, Turssi CP, Faraoni-Romano JJ, Serra MC. Susceptibility of bleached enamel and root dentin to artificially formed caries-like lesions. Am J Dent 2007;20:173-176.

18. Costa JB, Mazur RF. Effects of new formulas of bleaching gel and fluoride application on enamel microhardness: an in vitro study. Oper Dent 2007;32:589-594.

19. White DJ. Reactivity of fluoride dentifrices with artificial caries. Effects on early lesions: F uptake, surface hardening and remineralization. Caries Res 1987;21:126-140.

20. Featherstone JDB, O'Reilly MM, Shariati M. Enhancement of remineralisation in vitro and in vivo. In: Leach SA (Editor) Factors relating to demineralization and remineralization of the teeth. Oxford, IRL Press, 1986, 23-34.

Accepted May 26, 2008 